\title{
Re-Introducing Structure: An Historical Analysis and Structural Account of Political Cultures in the Prairie Provinces
}

\author{
Matthew Daniel Sanscartier \\ University of Manitoba, Department of Sociology
}

In this paper, I conduct an historical structural analysis to explain the preservation of political cultures across the Canadian Prairie Provinces. Taking into account Alberta's historically conservative climate and bootstrap individualism, Saskatchewan's historically left-leaning policy environment, and Manitoba's moderate culture between its two prairie compatriots, I explain how these different cultures have persisted using a "polity-centred" approach. Perhaps the most popular explanation for such a "prairie paradox" is "fragment theory", or looking at different "waves" of settlers including Loyalists, Americans, and early Ontarians, across the prairies. Scholars such as Alan Cairns and Jared Wesley have critiqued this approach, arguing that it is the structure of federalism itself that preserves these cultures over time, or that it is the agency of political parties and their campaign literature that reflects political culture back at their populations. A "polity-centred" approach, as I present it here, synthesizes these two critiques of fragment theory to look at how structures both affect political agents and provide tools to affect political culture in their provinces. This is accomplished by, first, a more general examination of how the Canadian federal structure influences political parties; second, a discussion of how political parties use structure to affect discourse in a province, preserving and/or changing provincial political culture. I conclude that politycentred approaches should be taken more seriously by sociologists and political scientists when looking at political cultures, and that this approach is useful for examining the cultures of other states and substates.

\section{Keywords: polity-centred; sub-state; culture; prairies; federalism.}

Dans ce document, je fais une analyse structurelle historique pour expliquer la préservation des politiques culturelles des provinces des Prairies canadiennes. En tenant compte du climat conservateur historique de l'Alberta et de l'individualisme en circuit fermé, de la politique de l'environnement, historiquement à tendance gauchiste, de la Saskatchewan et de la culture modérée du Manitoba située entre ses compatriotes des deux Prairies, j'explique comment ces différentes cultures ont perduré en utilisant une approche « de régime politique centré ». L'explication la plus populaire à un tel «paradoxe des Prairies » est probablement la «théorie de la fragmentation » ou la considération de différentes «vagues » de colons dont les Loyalistes, Américains et les Premiers Ontariens s'établissant dans les Prairies. Des spécialistes tels qu'Alan Cairns et Jared Wesley ont critiqué cette approche, soutenant que c'est la structure du fédéralisme elle-même qui préserve ces cultures au fil du temps ou que c'est l'organisme des parties politiques et leur documentation de campagne électorale qui reflète la culture politique à sa population. Une approche de régime politique centrée, telle que je la présente ici, résume ces deux critiques de la théorie de la fragmentation pour expliquer comment elles affectent les programmes politiques et fournissent les instruments pour influencer la politique culturelle dans leurs provinces. Cela s'effectue d'abord par une analyse plus générale des influences de la structure fédérale canadienne sur les parties politiques et comment elle est exercée; deuxièmement, par une discussion évaluant comment les parties politique utilise la structure pour affecter le discours dans une province, en préservant et/ou changeant la culture politique provinciale. Je conclus que les approches de régime politique centré devraient être prises plus au sérieux par les sociologues et les politicologues lorsqu'ils se penchent sur les cultures politiques et que cette approche est utile à l'analyse des cultures d'autres états et sous-états.

Mots clés: politie-centrée; sous-états; cultures; Prairies; fédéralisme. 


\section{Introduction}

While scholars of political culture often take the nation-state as their primary unit of analysis, substates and institutions also work to sustain a variety of political cultures within the same national border (Henderson, 2010a). While this has been shown to be true in Canada, fundamentally linked with the Canadian federal structure, scholars have historically disagreed on how and why federalism fosters such cultural variation, and whether such variation is a positive or negative development (Clarke, Pammett, and Stewart, 2002; Cardinal and Brady, 2009; Behiels, 2010). Political culture, as defined by Jared Wesley (2011, p. 4) refers to a set of taken-for-granted assumptions about the political world and what that world should look like, according to its subjects. The Canadian prairies are a good example of the diversity of political cultures across Canada. Despite their geographical and economic similarity, Canadian everyday wisdom and scholarly research has held that Albertans are Canada's most politically conservative population; Saskatchewan, collective and left-leaning, while Manitoba is moderate and temperate, somewhere between its two prairie compatriots. This phenomenon is what Wesley (2011) has called the "prairie paradox" (p. 2).

One explanation for the existence of this "prairie paradox" are various settler fragments that gradually moved into the Canadian West, each with their own political culture. This account is known as "fragment theory" (Hartz, 1964). Theorists David Bell (1992) and Nelson Wiseman (1996b) describe these "waves" of settlers that moved into the Canadian West, consisting of early Ontarians, the British working class, and Americans, which led to the deep-rooted and varied political cultures scholars in the prairie provinces today. Such deep-rootedness and variation, according to this account, are products of a socio-historical "congealing" around these "fragments" of settlers (Stewart, 1990). Jared Wesley (2011) critiques this approach, arguing that such an explanation does not discuss how these provinces' cultures have remained so consistently different over time. He instead argues it is the agency of political parties that, through campaign rhetoric and leadership, transmits such culture to provincial electorates over time. Alan Cairns (1977) also critiques such an approach, albeit differently. He has argued that we see diverse political cultures across Canada because of the federalist structure, rather than any a priori settlement patterns. The seeds of difference, for Cairns, were sown when Canada took on the system of federalism. The product is then sown through the functioning of that system.

The aim of this paper is to reconcile these two critiques of fragment theory to give a new account of how the Prairie Provinces have sustained their diverse political cultures. Using a "politycentred" or "neo-institutionalist" approach (Olsen, 2002), I will argue that Canada's federal and provincial political structures are central to explaining the diverse political culture among the prairies. Specifically, the political party agency to which Wesley (2011) refers has been influenced by structure, both in that such agency has been structured and utilizes structure in transmitting diverse political cultures in different provinces. First, I will discuss conceptual and theoretical problems associated with "political culture" in the literature, and explain how a polity-centred analysis is appropriate given such problems. Second, I will explain how structure both influences, and is influenced by, political agency (such as that of political parties and citizens), establishing it as a key pillar in any analysis of political culture. Last, I apply this structural analysis in a more specific manner, examining the interacting structures of parliaments and political party agencies in Alberta, Saskatchewan, and Manitoba. Although I focus here only on the prairies for the purposes of brevity and their economic and geographical similarity, I conclude that provincial state structures are key to transmitting and influencing provincial political cultures. This analysis therefore has 
general utility, both nationally and sub-nationally. I also conclude with some general comments concerning the value of polity-centred approaches, breaking the scholarly muteness on such approaches to political culture. In doing so, I contribute to the "urgent call" for a synthesis of structure and culture through a socio-political lens (Rubinstein, 2001, p. 8).

\section{Political Culture, Regions, and Provinces}

Many attempts have been made to define and classify political culture. Landes (1995, p. 294) offers a definition slightly different than Wesley's: "the attitudes and beliefs people have about the political system". It delineates what counts as legitimate in the public sphere, and the extent of political participation for individuals. Although definitions like this are typical in the literature, the concept of political culture itself has been critiqued heavily. According to Ian Stewart (1990), there are three historically dominant critiques of "political culture": it is too abstract (is it more than the sum of what individuals think, or does it end with the individual?); there are simply too many explanations as to why political cultures exist and what influences them; last, that most scholars of political culture have ignored the role of power and elite influence on how people perceive political systems. Despite these criticisms of the concept, however, Stewart also notes that "[t]o deny the existence of political cultures may be foolish" (ibid, 90). Despite the definitional issues plaguing the term, then, it denotes something that is very real.

Trying to apply the idea of "political culture" to a Canadian context brings with it even more baggage. One of the more pertinent issues is whether regions or provinces qualify as the main unit of analysis with respect to political culture. Regions have been a dominant variable in studies of Canadian political culture, with "the Prairies", "Atlantic Canada", and "Central" Canada (or Ontario and Quebec) grouped together (MacIvor, 2010). Recently, McGrane and Berdahl (2013) have made the case that political attitudes cut across provincial boundaries, indicating that regional variation may be more important than provincial variation. Nonetheless, they maintain that "province of residence is a significant determinant of political culture" (ibid, 488). Alisa Henderson (2010a) has also shown that despite the fact that regions have been the dominant variable, provincial borders do contain within them varying levels of trust in government, and that differences in this variable do exist within regions. The result is that citizens of different provinces (even of those within the same region) will vary in their support for various social programs, government intervention, and so on. In addition, she explains this province-bound variation as the capacity for institutions to "create a unique political environment that prompts specific expectations about government performance...support for an active or a small state...or community belonging" (Henderson, 2010b, p. 441). Not only are there some sort of differences within regions to be explored then, they are likely to do with the fact that sub-states have the capacity to transmit cultural variations through "unique political environments." Precisely how this is done so will be explored further below.

The work of Nelson Wiseman (1996a, 1996b, 2007) provides some guidance to analyzing political culture in a Canadian context, given these issues. The notion that political cultures are concurrent with provincial boundaries has been buttressed by his analyses. Wiseman has argued that with the shift of the Canadian federal system from intrastate (or institution-building and representation) to interstate (competition among substates), provinces have become a primary mechanism of identity rather than region $(2007$, p. 116). The failure of the Canadian electoral system and senate to adequately represent regions is also to blame for the disintegration of "region" as a salient identity (Bickerton, 2007). One is now more likely to identify as "Albertan" or 
"Manitoban" than "Western Canadian", although this was not always the case. Further, Wiseman (1996a, 2007) has been able to provide some clarity to the cultures of individual Canadian provinces. His empirically based "metaphorical images" for Alberta, Saskatchewan, and Manitoba are affectionately termed the "Prairies' America", "Prairies' Britain", and "Prairies' Ontario", illustrating the individualist, collectivist/deferential, and temperate attitudes that Wesley (2011) speaks of, respectively. This conceptualization of political cultures as contained within their respective provinces makes the concept of "political culture" ripe for a neo-institutional analysis by providing us with a key question: how might the structure of the Canadian federal system, and provincial sub-states, help sustain the political culture of their populations over time?

While I intend to demonstrate how provincial state structure is a key variable when discussing provincial political cultures, it should be noted there are multiple influences and explanations as to their existence, as Stewart (1990) notes. Wiseman (1996a), for example, discusses staples theory, formative events, quakes, and settler patterns (fragment theory) as all playing a role in the development of political cultures. The fact that the prairies harboured a great resentment for the economic protectionism of Central Canada after Confederation, for example, would have had an impact on the West as a whole, interacting with other factors (Henry, 2002). This might include the Winnipeg General Strike, the Great Depression, or the oil boom in Manitoba, Saskatchewan, and Alberta, respectively. Fisherman rely extensively on their private ownership over boats, for example, and so Atlantic Canadians may have a significant individualist component to their political culture. Wesley (2011, p. 33) notes, however, that such explanations fail alongside fragment theory to explain the persistence of divergent cultures in these provinces. By synthesizing the structural critique by Cairns, and the agential critique of Wesley, I invoke a sentiment once articulated by Whittington:

Structures of the Canadian political system....are some of the objects toward which we acquire attitudes. Conversely, however, the political structures must reflect the dominant values of our political culture if they are to be effective...One way or the other, the analysis of political structures is an essential and integral companion to the political culture approach. (1978, p. 150, emphasis added).

By examining the ways in which political parties both use and are constrained by their provincial state structures, we acknowledge that institutions themselves directly influence the "cultural and political complexion" of a population by shaping social policy and bureaucratic structures (Banting, 1987, p. 39). It is to such an examination I now turn.

\section{State Structure and Permanence of Political Parties}

Since Confederation, Canada's federalist structure has facilitated increasing decentralization that remains a significant force today. Provinces, under section 92(13) of the Constitution Act, 1867 (property and civil rights), have become increasingly autonomous, gaining residuary powers beyond what the Founding Fathers had originally intended (Bakvis, Baier and Brown, 2011). Alan Cairns, in his work, has argued that the phenomenon of Canadian decentralization is a product of the structure of federalism. He notes that many federalists and theorists fervently critiqued the Judicial Committee of the Privy Council (JCPC) for its decentralizing decisions, and having appropriating far more power to the provinces than what was intended at confederation (Cairns, 
1971). He articulates an alternate view; put simply, that it is "far too easily overlooked, because of idolatry with which the Fathers and their creation are often treated, that in the long run centralization was inappropriate for the regional diversities of a land of vast extent" (ibid:, p. 320). The beginnings of the provinces' regional diversity across the prairies and Canada, he concedes, are explained well by fragment theory. The notion that different settlers established a patchwork of varying cultures can help to account for initial centrifugal thrusts (Wiseman, 1996b).

The issue that Cairns raises with such an approach, however, is that it "pays inadequate attention to the possibility that the support for powerful, independent provincial governments is a product of the political system itself...such support need not take the form of a distinct culture [as] these are conventionally understood" (1977, p. 699). The appropriate theoretical framework to explain the continued variation of cultures across Canada is thus not historical settlement patterns, but the system that formed itself around such patterns. Provincial governments, part of a system that is necessarily power-sharing and was introduced to a land consisting of such varying settler cultures, inevitably sought political autonomy. The JCPC, in this context, was simply a catalyst for decentralization, rather than its instigator (Bakvis et al., 2011, p. 9). Decentralization has been the norm that continues to present day (Salmon and Keating, 2001; Bakvis et. al, 2011). In short, it was the structure of federalism that encouraged the aggressiveness of provinces, which "steadily [extended] their tentacles of control, regulation, and manipulation into society...playing a "steering role" (Cairns, 1977, p. 706). Such a "steering role" has enabled provinces to move their populations further away from one another, culturally speaking. Exactly how they have done so will be further explained in the analysis section of this paper.

Another structural and countervailing force to this decentralization of power at the federal level has been the centralization of power at the provincial level. This has intensified the role structure as a whole plays in the ideological trajectory of government, and therefore political culture. The Premier is the most important and powerful player in any provincial government. McArthur (2007, p. 247) notes that, by consolidating power over institutional features such as cabinet committees, provincial governments have developed the maneuvering space needed to guide their respective governments in different directions in policy and culture. The combination of the Westminster model, with a bias toward a powerful and dominant executive branch (Smiley, 1987), combined with the decentralizing tendencies of Canadian federalism, have led to a cultural environment where this relative ideological autonomy among provinces have become possible. Moreover, the Canadian approach to ensuring interests are represented at the cabinet level (both federally and provincially) has been to ensure diverse representation within the executive, rather than create external checks on the executive (Smiley, 1963). Therefore, the attempts to make executive branches sensitive to diverse interests have gone with the grain of centralized power, rather than against. Take for example Saskatchewan, under the leadership of Tommy Douglas. The province was able to develop a radically different (at the time) planning structure at the behest of their Premier, including a Planning Board which operated as a support body to cabinet. Specifically, it was "mandated to address the shortcomings of capitalism, which emphasized production for profit rather than human needs" (McArthur, 2007, p. 243). Social policy and spending became a priority, rather than business-friendly policy.

In addition, bureaucratic configurations in the provinces have gotten closer to, and intense with, the Premier as the centralization of power has increased. Bureaucracies have claimed significant authority as a result of this development (Dunn, 1996). As such, when the Devine conservatives took control of Saskatchewan in the 1980s, they had a difficult time undoing many of the policy structures put in place by the previous Co-operative Commonwealth Federation (CCF) 
and the New Democratic Party (NDP). Similarly, in Alberta, Premiers Lougheed and Getty had a difficult time creating policy-creation structures after Manning's complete overhaul of the system (McArthur, 2007). The point here is that the structural trajectory of provincial sub-states becomes key in looking at why varied political cultures have continued to be so different among the prairies.

Wesley (2011) argues that the agency of political parties, through their leadership, has reflected and transmitted cultures back onto populations - the approach I am presenting here is that they do so equally through such structural policy set-ups, and are guided by such set-ups. That Alberta has historically possessed a minimalist policy framework, making it difficult to pass social policy - and that Saskatchewan has historically had the opposite - is the starting point for illustrating that political parties can (and do) transmit culture through structure. Even when the electorate in these provinces chose an ideologically different leader (such as the Devine conservatives in Saskatchewan), policy continued to move in more or less a similar direction due to bureaucratic and structural inertia. While agency remains an important factor, structural analyses look at the ways in which political institutions shapes the behaviour of, and provides a limited set of tools for, political parties which transmit cultures among the provinces.

As Cairns (1977, p. 707) notes, "[w]hile the jurisdiction of a province lacks the comprehensive coverage enjoyed by the government of a unitary state, it is a sufficiently impressive base of governmental power to elicit visions of futures to be pursued." Structure provides opportunities for provinces to both create and pursue such visions, and the tools through which those visions can be realized - part of which involves their political cultures. In the analysis that is to follow, I will show how federal and provincial structures, beyond the control of any political actors, have influenced and nurtured the very different political cultures we see among the Canadian prairies provinces of Alberta, Saskatchewan, and Manitoba. The "visions" that Cairns speaks of, in other words, are nurtured by, and depend on, political structure to be fulfilled. The prairies will be discussed for two main reasons. First, for purposes of brevity. An analysis of all ten provinces is beyond the scope of this paper. Nonetheless, the conclusions will provide a tentative commentary of how this analysis could apply to other provinces. Second, because of Wesley's (2011) so-called "prairie paradox" - that these provinces are similar to one another on many other measures (including economic staples, geography, and acquisition of natural resources throughout confederation) besides political culture.

\section{Structural Influence on Political Parties, their Ideology, and Culture}

The idea that political cultures stem from historical waves of "settler fragments", or "fragment theory", is a cornerstone of political culture literature. Nonetheless, as Wesley (2011, p. 34) points out, "[w]hereas Wiseman argues there would have been no Tommy Douglas without a collectivist political culture...the persistence of Saskatchewan's social democratic impulse owes as much to Douglas's leadership as vice versa". Looking at structure, the first question then becomes, how were political agents like Tommy Douglas influenced by structure to transmit such cultural "impulses"? One important point of investigation is the Canadian parliamentary system itself. According to Brownsey (2005, p. 212), "[w]hile institutions do not determine outcomes, they do 'provide an enabling, restricting, or stimulating context for individual or corporate action"'. Olsen (2002, pp. 152-153) discusses this idea in the Canadian context at both the federal and provincial level in Canada. Strict party discipline and bloc voting among parties encourages dissenting voices to break off and create their own parties. The Great Depression among the prairies, for example, resulted in political disagreements and the split between ideological factions that led to the creation 
of both the Co-operative Commonwealth Federation (social democrats), Social Credit (populist/social conservatives), and Progressive Conservative (social conservatives) parties in the Alberta, Saskatchewan, and Manitoba (Robin, 1972). This political entropy is further exacerbated at the provincial level, where the smaller number of seats at this level heavily encourages strict party discipline (Coleman a\& Skogstad, 1990, p. 18). Noting this structural feature of the Canadian polity sheds some light on the "stimulation" of action and political behaviour among provincial parties.

In addition to the rule of bloc voting in Canada, parliamentary politics are adversarial. This is true in Canada to a large extent. At both the federal and provincial levels, "[a]dversarial polities promote the role of public debate, are hostile to inter-party coalition and power sharing, and discourage the effective functioning of investigative machinery within Parliament" (Coleman and Skogstad, 1990, p. 18). The structural influences of bloc voting and adversarial politics therefore encourage hostility among the ideologically concentrated parties. Provincial parties need to create strategic "alternatives" to the mainstream ideas and party in a province at any given moment, which affects the political culture in adverse ways. For example, a left-wing party may try to push political discourse to the left when threatened by a new right-wing party, or vice versa. Such structural features of Canadian provincial politics heavily influenced the party discourse and rhetoric that transmitted and influenced political culture among the Prairie Provinces. For example, the rhetoric of the 1940s campaigns involving Manning's Social Credit (Alberta) and Douglas's CCF (Saskatchewan) capitalized on these structural features to a large extent. Tommy Douglas's political success in Saskatchewan was key for Manning's movement of Albertan political culture to the right, using the CCF as a foil (Wesley, 2011, p. 68). The Albertan Social Credit ideology presented a free-enterprise and capitalistic society as the solution to the looming "socialist menace" just next door. Likewise, Tommy Douglas too engaged in a form of "provincial boosterism" that downplayed Alberta's laissez-faire and isolationist approach, and spoke of Saskatchewan's style of planning as being worthy of export to the rest of Canada (Wesley, 2011, p. 133).

The point is that these two leaders pushed their provincial cultures away from one another, and were able to do so through (and because of) structure. Their respective parties, the CCF and Socreds, monopolized their respective ideologies in their provinces through bloc voting. Further, the federal and antagonistic political structure itself allowed them both to compare their parties to one another, which served to stretch discourses further left and right, respectively. Alberta could not have pushed itself rightward through fear-mongering if it did not have a contrast off of which to push. In Manitoba, much of this same issue is at play. NDP Premier Schreyer relied heavily on rhetoric that emphasized the "out-datedness" of the Progressive Conservative party that had been in power for so long before him. This rhetoric of "moving forward" has persisted in Manitoba to present-day. In fact, premiers in Manitoban politics typically compare themselves to their predecessors, rather than their contemporaries (Wesley, 2011, p. 219). This reflects and transmits the culture of moderation and temperance found in Manitoba back at the population; not necessarily better than other provinces or ideologies but wanting to "move forward" all the same. Here, we still see the antagonistic political structure at play; these ideologically concentrated parties compare themselves to others and subsequently push discourse in their preferred direction. By comparing themselves to predecessors instead of contemporaries, Manitoban political parties have avoided the entropy of pushing discourse "too far" left or right, preserving a middle ground by instead pushing "forward". As all parties are encouraged to do this, voters essentially must pick some form of concentrated ideological agent in a highly fragmented and entropic political field, more so than Americans. As such, the culture is influenced along with parties that are structurally influenced to 
behave in particular ways. While the claim here is by no means that structures determine behaviours of parties, it is rather that such parties have been formed by and have capitalized on these federal and antagonistic structures to shape provincial political cultures.

In these ways, the agency of political parties central to the thesis of Wesley's (2011) analysis is shaped by the federalist structure, and with it, the political culture among the prairies. However, provincial political parties also have available to them a structure that helps to further transmit political cultures over time. This comes primarily in the form of institutional features, such as policy planning committees and other cabinet committees that serve to buttress or decline what is called state autonomy. State autonomy is defined as "the degree of independence from societal groups possessed by state actors when they formulate policy objectives...the goals of an autonomous state...are internally generated and not simply reflective of societal interests or demands" (Coleman and Skogstad, 1990, p. 15). Through such features, increasingly centralized and autonomous provincial governments over the course of Canadian federalism have been able to create or dismantle such committees to insulate or de-insulate themselves from the public, more effectively creating policy which, in turn, can guide a region's political culture. This concept fits in well with Cairns' (1977) notion of provinces as acting in their own interests, establishing their own "visions" of the future. More or less insulation from the public, depending on the ideology of political parties' agency, can facilitate whatever "visions" for which such agency is aiming. As Skocpol (1985, p. 14) notes, state autonomy is not fixed; "it can come and go". What she calls the "structural potentials" of states can change. A key part of this is the size and partisanship of bureaucracy - neutrality and independence means more state autonomy (Skocpol, 1985; Coleman \& Skogstad, 1990). Applying such a concept to the provincial level, I pose the argument below that at the provincial level across the prairies, centralized and powerful agents use institutional structure to manipulate their level of state autonomy. In turn, this has guided the provinces down different cultural paths.

Another concept that will be employed in the subsequent analysis of each prairie province is policy feedback. This refers to "the impact that existing social policies have on subsequent policymaking. This influence may be intentional, or it may be unanticipated and unplanned" (Olsen, 2002, p. 160). Legislation or policy that is passed at an earlier time can have a significant effect on future action, constraining or stimulating behaviour of agents in the state. In the provincial context, this means that previous actions taken by Premiers or their planning committees can significantly impact the options available to subsequent governments. Policy feedback also has some significance in explaining how provincial structure has influenced cultures within the different prairie regions. The analysis that follows uses both state autonomy and policy feedback in examining the structural histories and political cultures of Alberta, Saskatchewan, and Manitoba, respectively.

\section{Alberta, Saskatchewan, and Manitoba: Three Structures, Three Cultures}

Throughout the history of Alberta's existence as a province, political parties have transmitted a political culture composed heavily of individualism, populism, and autonomy (Wesley, 2011, p. 56). The initial settler fragment culture that composed Alberta, primarily American, has lived on in this way. Premiers and the Albertan provincial government have used and manipulated the structure of their institution to lower state autonomy, making it more difficult to pass social policy and to transmit a political code of self-reliance to its citizens over the decades. As Brownsey (2005, p. 224) points out, the premiers of Alberta have typically preferred strong, centralized decision- 
making in their offices. Premiers Manning and Klein, for example, completely dominated their cabinet; an option given to them by virtue of a provincial state structure that concentrates as much power in the hands of the premier as he or she wishes (McArthur, 2007). Manning's provincial campaigns ran primarily on "laissez-faire liberalism" and "plebiscitarian populism", while Klein focused on "bootstrap individualism" (Wesley, 2011, p. 57). Their centralized style of decision making capitalized on the malleable structure of provincial governments to transmit these codes throughout their political tenures. When Klein took control, for example, he reduced the number of standing committees in government from fifteen to three (Brownsey, 2005, p. 218). Policy committees have historically been underused in Alberta compared to the other Prairie Provinces. This has created difficulty in passing social policy under the centralized and minimalist structure created by Albertan Premiers; policies must be sponsored by a minister and pass through at least two other committees, then go through a final review and require public input (Brownsey, 2005, p. 221). Committees in this way are used not to insulate government from interest groups, as Saskatchewan has done, but rather, internally fragment the process through a system of checks, slowing policy down

The autonomy of the Albertan state in this way is lowered, and serves to translate the political culture of self-reliance and populism into policy. Through the request of public input, Albertans are allowed to interact with the government to mutually reproduce this culture via policy structures. In addition, the bureaucracy of Alberta has been less independent than in the other Prairie Provinces. When Klein was in power, for example, he and his chief of staff Rod Love "ensured [bureaucrats] viewed their role as political operatives and not as neutral members of the bureaucracy...the politicization of their role not only confused [some of] them but led to their dismissal" (Brownsey, 2005, p. 219). As a strong and independent bureaucracy is a keystone feature of an autonomous state, it was clear this was not part of the "vision" that Albertan Premiers did not have for their province. Even those Premiers who were less centralized than Manning and Klein, such as Peter Lougheed, found it difficult to create the structure for policy planning (Brownsey, 2005); the Albertan policy structure by then had been drenched with a populist and individualistic ethos. Policy feedback had helped to steady the political culture in the province. The Progressive Conservatives and Social Credit parties in Alberta infused the Albertan state structure with this individualist tint, which helped to transmit populism and individualism among Albertans. The lack of social policy and public spending relative to the other Prairie Provinces has translated (and still translates) the "codes" that Wesley speaks of into tangible ways of life for Albertans.

Saskatchewan, despite being what Marchildon (2005) calls Alberta's "Siamese twin", has had an historically opposite political culture to its Westward neighbour. To a large extent, the translation of its codes of "collectivism" and "dirigisme" into structure were performed by Tommy Douglas (Wesley, 2011). Saskatchewan has historically taken the lead among the provinces in terms of social planning and developing policy committee structure, increasing state autonomy. As Rasmussen and Marchildon (2005, p. 188) note, the CCF under Douglas pioneered large amount of interconnected boards and committees, including the Economic Advisory and Planning Board, Government Finance Office, and Treasury Board committees - a "classic administrative troika" that would persist for another fifty years after creation. Such a planning structure facilitated what George Cadbury called the "marriage of the politician and the technician" (Rasmussen \& Marchildon, 2005, p. 189) - clearly, a collaborative effort in the creation of social policy. This stands in stark contrast to Alberta's systems of checks and internal fragmentation. Many other committees, treasuries, and planning boards spawned from this "troika", and persisted through other Premierships. Ross Thatcher, Douglas's successor, disliked committees and had a leadership 
style closer to that of Manning or Klein (Rasmussen \& Marchildon, 2005, p. 192). Nonetheless, it was difficult for him to dismantle the complex set of committees, and when Blakeney's NDP took over in 1971, things once again became "business as usual" with respect to policy planning, and even more structured than under Douglas's CCF. Thus, even when voters opted for a party with a different ideology, the state structure in Saskatchewan still maintained its overarching trajectory of a policy-planning orientation. The structure was reflecting a culture of collectivism and dirigisme back at Saskatchewanians through tangible social policy.

Saskatchewan is a good historical example of what Coleman and Skogstad (1990, p. 29) refer to as a state-directed policy network. These include "highly autonomous, coordinated state agencies" with minimal influence from the outside. Committees and the "administrative troika" established over Saskatchewan's history provide insulation from external influences, creating its more autonomous network. Policy feedback also has played a large role in sustaining Saskatchewan's autonomous and dirigisme-oriented structure. The Civil Service Act passed by Douglas's CCF had three lasting, constraining features. First, it "limited the ability of the Douglas and subsequent governments in Saskatchewan to stack the public service with partisan individuals"; second, it increased government dependence on senior bureaucrats; third, it gave civil servants a constructive role in the creation of policy (Rasmussen \& Marchildon, 2005, p. 186). This Act helped to ensure that the planning tradition was firmly embedded within the Saskatchewanian state, and crystallized Douglas's promises of security and economic/social policy (Wesley, 2011) in structure. It did so, primarily, by enhancing state autonomy, insulating it from external sources that may try to de-stabilize the collectivist ethos its social planning structure implies. Public input and opposition have less access points to critique and slow down social policy, ensuring it is churned out more smoothly than in Alberta. Moreover, Saskatchewan's bureaucracy was made a more permanent, independent structure than its Albertan counterpart, which was highly partisan. A strong bureaucracy that knows its role well, as Coleman and Skogstad (1990) note, is necessary for state autonomy. We can see here that the agency of political parties that transmit a collectivist code have done so through the structure (via increasing insulation from outside sources, such as patronage politics), and have implemented a "vision" of the future in this way.

Manitoba, for its part, has been culturally located somewhere between its two companions to the West. Not far off individualist or collectivist, Manitoba has been described as possessing a culture of modesty and temperance (Wesley, 2011). Looking at the variation of its planning structures, historically, this notion lines up. Grace (2005) discusses the swelling and inflating of Manitoba's planning structure over several decades (also see Wiseman, 1996b). Duff Roblin, for his part, laid a foundation for an enhanced planning structure in Manitoba. However, he did not build to the extent that Douglas did in Saskatchewan. Walter Weir and Ed Schreyer capitalized on these somewhat, slightly expanding central planning units. Sterling Lyon dismantled many of these committees and planning processes, which were then re-instated by his successor Howard Pawley. State autonomy here can be seen to increase and decrease at the behest of various Premiers, paralleling the cultural tightrope that Manitoba walks between Saskatchewan and Alberta. The political "codes" that premiers have reflected back at Manitobans has been one of, generally speaking, "non-partisanship" or "progress before party"; that ideological motives should be placed aside for moving Manitoba "forward" (Wesley, 2011). Doer's ideology and campaign rhetoric, was one that was "middle-of-the-road", which compared him to predecessors rather than contemporaries. This particular rhetoric fit well with Manitoba's cultural trajectory, one that praised social progressivism coupled with fiscal conservatism (Wesley, 2011). It was translated into a provincial structure that saw some slight change under Doer, but no major shifts, keeping 
cabinet and committee sizes mostly unchanged (Grace, 2005, p. 179). Central agency support remained the same under Doer, and the Policy Management Secretariat (PMS) served and still serves as a form of fiscal "check" on policies.

Here, we see elements of both Albertan and Saskatchewanian structure. Checks like that of the PMS still serve to strike a balance between social progressivism and fiscal conservatism, while retaining enough state autonomy (i.e., not completely fragmenting the system) to pass policy. Using a polity-centred analysis, we see that the Manitoban sub-state has not historically been as fragmented as Alberta's state, nor as insulated and autonomous as Saskatchewan's. It is the structural response to a culture and ideology that finds itself halfway between the other two provinces, wanting the social security of Saskatchewan with the fiscal conservatism of Alberta. Structure is not separate from culture here, but works in tandem to maintain a middle cultural ground between Alberta and Saskatchewan. Settler cultures of modesty have been reflected through political parties practicing the same breed of rhetoric (self-comparisons to predecessors, not contemporaries) and a structure that retains enough autonomy to keep policy in play, without becoming a Saskatchewan-style form of planning ("locked in" to creating policy) or Alberta's clunky and fragmented sub-state. This is seen both over a number of Premiers, as evidenced by the buoying of Manitoba's cabinet structures, and within tenures of Premiers like Duff Roblin and Gary Doer, both of whom balanced on the ideological and structural tightrope. This renders the Manitoban structure more flexible than the other two; whereas it has been historically difficult to pass policy in Alberta, and easier in Saskatchewan, the tangible policy realities for Manitobans stems from somewhere in between those two realms. State structure must be kept flexible precisely to avoid the aforementioned, potential runaway influences on either side that occurred in Saskatchewan and Alberta, taking ideology further to either side than Manitobans would like to see. The fact that the structure has been kept flexible in this way is a testament to how it has reflected themes of modesty and temperance back at the population.

\section{Conclusion}

I have attempted to show here how each prairie province has, in a context of their increasing and historical appropriation of autonomy and power, has created and fulfilled its own "vision" of the future (Cairns, 1977). Although settler patterns help to explain to some extent the establishment of various cultures among the Canadian prairies, it is the structure that developed around these that has nurtured and transmitted varying cultures through time, translated by the agency of political parties who are influenced by, and use, these structures. Political parties across the prairies, ideologically distilled and volatile due to Canada's parliamentary and adversarial system, have capitalized on the historical processes of federal decentralization and provincial centralization of powers to guide their provinces in culturally separate directions. Structure thus becomes a primary variable in explaining what Wesley (2011) calls the "prairie paradox". By re-introducing structure into cultural accounts in this way, we might help to rectify the shortcomings of separate structural and cultural socio-political theories. Gans (2012) notes that that main commonality between structural and cultural accounts is the quest to find power in their respective theoretical infrastructures; if we can find ways to articulate them to one another, we might be able to fill explanatory lacunas we find in both. One question posed by an analysis I offer in this paper is how structural potentials change the power available to political parties at any given time - and how this can affect how citizens view the political process in their province. 
This analysis is predicated on a polity-centred approach, which considers the state as having some autonomy from social pressures and the ability to gather its own resources, and as constraining and providing opportunity for political entrepreneurs (Olsen, 2002, p. 142). Observing how this structure has the ability to constrain and channel political agents in passing batons of conservative, social-democratic, and moderate political cultures across populations is valuable. Given its ability to shed light on old and (perhaps) tired phenomena, the polity-centred approach should be taken more seriously by political scientists, sociologists, and other scholars interested in political cultures. The new roles of the Quebec state during the Quiet Revolution, for example, could have had just as much impact on Quebecois political culture as vice versa. As the roles of education and healthcare passed from Church to State, the new, liberal culture of Quebec was bound up with processes of this transfer and newfound state autonomy (Dickinson \& Young, 2008). What it meant to be a citizen of Quebec was highly influenced by state activity, and could have had adverse effects on the political culture of that province (Jenson and Phillips, 2001). An analysis of Quebec's structural character, much like I have done here for the Prairie provinces, could give an alternative perspective concerning some of the historical behaviours in that province. The historical structural character of each province, in sum, is crucial for understanding political attitudes and behaviour in that province. It encompasses, to some extent, the agency of political parties and the various strategies they use for elections. Future research could also possibly investigate the extent to which this structural influence impacts election campaigns in other jurisdictions. Likewise, the structural character of any state or sub-state, as a political entity with an ability to gain a certain degree of autonomy from social groups, is important in discussing the behaviour of agents within its arena.

Political culture and federalism will perhaps always be something of a chicken-and-egg problem. Nonetheless, what I have attempted here is one viable explanation as to how political cultures have held up over the course of Canada's development as a nation. While this analysis focused on the Prairie Provinces for the purposes of brevity, and because of the similarity among these provinces, this analysis can feasibly hold for other provinces outside the prairies, and perhaps other states and/or sub-states altogether. A structural analysis such as this are attempts to situate political entrepreneurs as agents of change within their contexts, and as such, what constraints and opportunities their structures provide them. More generally, such an analysis might be applied to other provinces, sub-states, or possibly the international scene, and future research may be able to find fruitful conclusions by "bringing the state (or sub-state) back in".

\section{About the Author}

Matthew Daniel Sanscartier is a MA student in the Department of Sociology at the University of Manitoba. He can be reached at matthew.sanscartier@umanitoba.ca 


\section{References}

Bakvis, H., Baier, G., \& Brown, D. (2011). Contested Federalism. Don Mills, ON: Oxford University Press.

Banting, K.G. (1987). The Welfare State and Canadian Federalism (2 $2^{\text {nd }}$ ed.). Kingston and Montreal: McGill-Queen's University Press.

Behiels, M.D. (2010). Asymmetrical Federalism in Canada: Magic Wand or Breaking the Ties that Bind? In G. DiGiacomo \& M. Flumian (Eds.), The Case for Centralized Federalism (pp. 73-107). Ottawa: University of Ottawa Press.

Bell, D. (1992). The Roots of Disunity. Toronto: Oxford University Press.

Bickerton, J. (2007). Placeholder until I look up the actual name of the chapter. In A.G. Gagnon and B. Tanguay (Eds.), Canadian Parties in Transition (pp.411-436). Peterborough, ON: Broadview Press.

Brownsey, K. (2005). The Post-Institutionalized Cabinet: The Administrative Style of Alberta. In L. Bernier, K. Brownsey \& M. Howlett (Eds.), Executive Styles in Canada: Cabinet Structures and Leadership Practices in Canadian Government (pp. 208-224). Toronto: University of Toronto Press.

Burgess, M. (2009). Managing Diversity in Federal States: Conceptual Lenses and Comparative Perspectives. In A.G. Gagnon (Ed.), Contemporary Canadian Federalism: Foundations, Traditions, Institutions (pp. 428-440). Toronto, ON: University of Toronto Press.

Cairns, A.C. (1971). The Judicial Committee and Its Critics. Canadian Journal of Political Science, 4, 301-345.

- (1977). The Governments and Societies of Canadian Federalism. Canadian Journal of Political Science, 26, 695-725.

Cardinal, L., \& M-J Brady. (2009). Citizenship and Federalism in Canada: A Difficult Relationship. In A.G. Gagnon (Ed.), Contemporary Canadian Federalism: Foundations, Traditions, Institutions (pp. 381-404). Toronto, ON: University of Toronto Press.

Clarke, H.D., Pammett, J.H., \& Stewart, M.C. (2002). The Forest for the Trees: Regional (Dis)Similarities in Canadian Political Culture. In L. Young and K. Archer (Eds.), Regionalism and Party Politics in Canada (pp. 43-76). Don Mills, ON: Oxford University Press. 
Coleman, W.D. \& Skogstad, G. (1990). Policy Communities and Policy Networks: A Structural Approach. In W.D. Coleman and G. Skogstad (Eds.), Policy Communities and Public Policy in Canada: A Structural Approach (pp. 14-33). Mississauga, ON: Copp Clark.

Dickinson, J. \& Young. B. (2008). A Short History of Quebec (4 ${ }^{\text {th }}$ ed.). Kingston \& Montreal: McGill-Queen's University Press.

Dunn, C. (1996). Premiers and Cabinets. In C. Dunn (Ed.), Provinces: Canadian Provincial Politics (pp. 181-200). Peterborough, ON: Broadview Press.

Gans, H.J. (2012). Against culture versus structure. Identities: Global Studies in Culture and Power 19, 125-134.

Grace, J. (2005). Cabinet Structure and Executive Style in Manitoba. In L. Bernier, K. Brownsey \& M. Howlett (Eds.), Executive Styles in Canada: Cabinet Structures and Leadership Practices in Canadian Government (pp. 171-183). Toronto: University of Toronto Press.

Hartz, L. (1964). The Founding of New Societies. New York: Harcourt, Brace \& World, Inc.

Henderson, A. (2010a). 'Small Worlds' as Predictors of General Political Attitudes. Regional \& Federal Studies 20, 469-485.

Henderson, A. (2010b). Why Regions Matter: Sub-state Polities in Comparative Perspective. Regional \& Federal Studies 20, 439-445.

Henry, S. (2002). Revisiting Western Alienation: Towards a Better Understanding of Political Alienation and Political Behaviour in Western Canada. In L. Young and K. Archer (Eds.), Regionalism and Party Politics in Canada (pp. 77-91). Don Mills, ON: Oxford University Press.

Jackson, R.J., \& Jackson, D. Politics in Canada: Culture, Institutions, Behaviour and Public Policy ( $5^{\text {th }}$ ed.). Toronto, ON: Prentice Hall.

Jenson, J. \& Phillips, S.D. (2001). Redesigning the Canadian Citizenship Regime: Remaking Institutions for Representation. In C. Crouch, K. Eder, \& D. Tambini (Eds.), Citizenship, Markets, and the State (pp. 69-89). Oxford, UK: Oxford University Press.

Landes, R.G. (1995). The Canadian Polity: A Comparative Introduction (4 ${ }^{\text {th }}$ ed.). Scarborough, ON: Prentice Hall.

MacIvor, H. (2010). Parameters of Power: Canada's Political Institutions ( $5^{\text {th }}$ ed.). Toronto, ON: Nelson.

McArthur, D. (2007). Policy Analysis in Provincial Governments in Canada: From PPBS to Network Management. In L. Dobuzinskis, M. Howlett, and D. Laycock (Eds.), Policy Analysis in Canada (pp. 238-264). Toronto: University of Toronto Press. 
Marchildon, G.P. (Ed.). (2005). The Heavy Hand of History: Interpreting Saskatchewan's Past. University of Regina: Canadian Plains Research Centre.

McGrane, D., \& Berdahl, L.. (2013).'Small Worlds' No More: Reconsidering Provincial Political Cultures in Canada. Regional \& Federal Studies, 23, 479-493.

Olsen, G. (2002). The Politics of the Welfare State. Don Mills, ON: Oxford University Press.

Rasmussen, K., \& Marchildon, G.P.. (2005). Saskatchewan's Executive Decision-Making Style: The Centrality of Planning. In L. Bernier, K. Brownsey \& M. Howlett (Eds.), Executive Styles in Canada: Cabinet Structures and Leadership Practices in Canadian Government (pp. 184-207). Toronto: University of Toronto Press.

Robin, M. (Ed.). (1972). Canadian Provincial Politics: The Party Systems of the Ten Provinces. Scarborough, ON: Prentice-Hall.

Rubinstein, D. (2001). Culture Structure \& Agency: Toward a Truly Multidimensional Strategy. Thousand Oaks, CA: SAGE.

Salmon, T.C., \& Keating, M. (Eds.). (2001). The Dynamics of Decentralization: Canadian Federalism and British Devolution. Montreal, QC and Kingston ON: McGill-Queen's University Press.

Skocpol, T. (1985). Bringing the State Back In: Strategies of Analysis in Current Research. In P.B. Evans, D. Reuschemeyer, \& T. Skocpol (Eds.), Bringing the State Back In (pp. 343). Cambridge, UK: Cambridge University Press.

Smiley, D. (1963). Constitutional Adaptation and Canadian Federalism Since 1945. Ottawa: Royal Commission on Bilingualism and Biculturalism.

Smiley, D., \& Watts, R. (1982). Intrastate Federalism in Canada. Toronto, ON: University of Toronto Press.

Stewart, I. (1990). The Study of Canadian Political Culture. In A.G. Gagnon and J.P. Bickerton (Eds.), Canadian Politics (pp. 89-105). Peterborough, ON: Broadview Press.

Wesley, J. (2011). Code Politics: Campaigns and Cultures on the Canadian Prairies. Vancouver: UBC Press.

Whittington, M.S. (1978). Political Culture: The Attitudinal Matrix of Politics. In J.H. Redekop (Ed.), Approaches to Canadian Politics (pp. 138-153). Scarborough, ON: Prentice Hall.

Wiseman, N. (1996a). The Pattern of Prairie Politics. In H.G. Thorburn (Ed.), Party Politics in Canada (pp. 428-445). Scarborough, ON: Prentice Hall. 


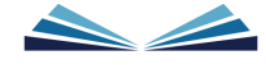

CANADIAN GRADUATE JOURNAL

OF SOCIOLOGY AND CRIMINOLOGY
CGJSC / RCESSC

Vol. 3 - Issue I No. 2 - Fall I automne 2014

(1996b). Provincial Political Cultures. In C. Dunn (Ed.), Provinces: Canadian Provincial Politics (pp. 21-62). Peterborough, ON: Broadview Press.

(2007). In Search of Canadian Political Culture. Vancouver: UBC Press. 